\title{
Conjugated linoleic acid (CLA) isomers in heat-treated vegetable oils
}

Oléagineux, Corps Gras, Lipides. Volume 8, Numéro 1, 94-7, Janvier - Février 2001, Fondamental

Auteur(s) : Pierre JUANEDA, Olivier CORDIER, Stéphane GREGOIRE, Jean-Louis SEBEDIO, Inra, Unité de nutrition lipidique, 17, rue Sully, BP 86510, 21065 Dijon Cedex, France.

Summary : The aim of this study was to quantify the conjugated linoleic acids (CLA) isomers present in frying oils and to elucidate their structures. For this purpose, used frying oils were collected in restaurants by the Laboratoire Interrégional de la Répression des Fraudes. Three samples of sunflower oils, one of peanut oil and one of rapeseed oil containing different levels of total polar compounds were analys-ed. The samples were converted to methyl esters using sodium methoxide and the CLA content was determinated by a combination of gas chromatography analysis on a $100 \mathrm{~m}$ CP Sil88 column and of silver-ion-high pressure liquid chromatography. The identification of the CLA isomers was carried out by gas chromatography coupled with mass spectrometry of the 4-methyl1,2,4-triazoline-3,5-dione adducts. The amount of polar compounds in the frying oils ranged from 30 to $53 \%$. The quantities of CLA from 0.4 to $0.5 \%$. The 9,11 and $10,12-18: 2$ were the major CLA isomers. Among them, the di-trans isomers represent about $50 \%$ of the total CLA.

Keywords : CLA, sunflower, rapeseed, peanut, heat treatment, frying.

Résumé : Le but de ce travail est de rechercher la présence d'isomères conjugués de l'acide linoléique (ALC) dans des huiles collectées en restauration par le Laboratoire interrégional de la répression des fraudes, et de déterminer les structures de ces composés. Trois huiles de tournesol, une huile d'arachide et une de colza ont été choisies pour leur teneur élevée en composés polaires (supérieure à $25 \%$ ). Les acides gras des huiles ont été méthylés par du méthanolate de sodium selon la méthode de Glass. Le pourcentage d'ALC a été déterminé par chromatographie en phase gazeuse sur colonne CP Sil88 de 100m. La teneur des différents isomères conjugués a été déterminée par chromatographie en phase gazeuse et par chromatographie liquide haute performence sur colonnes imprégnées au nitrate d'argent. L'identification des ALC a été réalisée par chromatographie en phase gazeuse couplée au spectre de masse des dérivés 4-méthyl-1,2,4-triazoline-3,5-dione. Les huiles contiennent de 30 à $53 \%$ de composés polaires. La teneur en ALC est comprise entre 0,4 et 0,5\%. Les 18:2 delta9,11 et 10,12 sont les isomères majoritaires. Les isomères géométriques di-trans représentent environ $50 \%$ des isomères conjugués de l'acide linoléique.

Mots-clés : ALC, tournesol, arachide, colza, chauffage, friture. 


\section{ARTICLE}

Fish oils are an important source of polyunsaturated fatty acids (PUFA) and are now widely used in health and nutrition [1-2]. For a long time, these molecules were shown to be of great importance in the prevention of a number of diseases such as inflammation, hypotriglyceridemic effect, allergies, diabetes or coronary heart disease [3-6]. Up until now, enzymatic methods for concentration of n-3 fatty acids have been used and several lipases have been studied and optimised in a number of reactions (hydrolysis, esterification, transesterification) [7-12]. Membrane filtration has proven valuable for the deacidification and degumming of oil, and is also a promising means for the separation and concentration of oils and fats [13-18].

\section{Materials and methods}

The production of n-3 polyunsaturated fatty acids from salmon oil upon a two-step enzymatic process was optimised. First of all, the extraction of total lipids was performed by centrifugation after protease hydrolysis of flesh and heads from $27 \mathrm{~kg}$ of Atlantic salmon (Salmo salar). Crushed substrates were subjected to the action of Neutrase 0.5 I supplied by Novo Nordisk. The enzyme was used at optimal temperature and $\mathrm{pH}$ values, and the enzyme to substrate ratio was fixed at $5 \%$. The reaction kinetics was monitored by measuring the degree of hydrolysis (DH) using the pH-stat method according to Adler-Nissen and Linder et al. [19-20].

The proteolysis was stopped with live steam injection when the $\mathrm{DH}$ reached $8-9 \%$ to preserve the functional and nutritional values of the hydrolysate. Before this step, total lipids were recovered by centrifugation.

In the second step, a stereospecific lipase sn-1-sn-3, namely Novozym SP398 was used in order to preserve the polyunsaturated fatty acids (PUFA), which are preferentially esterified at the $s n-2$ position in Atlantic salmon lipid [21]. Moreover, saturated and some monounsaturated fatty acids are known to be mainly located at the $s n-1$ and $s n-3$ positions [22-23].

Lipase hydrolysis was carried out in a $500 \mathrm{ml}$ thermostated reactor. The container was flushed with nitrogen and kept sealed during the reaction. The reaction mixture containing $200 \mathrm{~g}$ of oil and $200 \mathrm{ml}$ of distilled water was subjected to the lipase $\left(37^{\circ} \mathrm{C}, \mathrm{pH} 7.0,40\right.$ Kilo Lipase Units) under stirring using a high speed peristaltic pump.

After lipase hydrolysis, the mixture was subjected to filtration overnight, under the following conditions: reactor $350 \mathrm{ml}$ capacity, membrane Amicon $\mathrm{YM}$ 10, 10,000 D cut-off, 3 bars, $4^{\circ} \mathrm{C}$. The fatty acid composition of the permeate was analysed by gas liquid chromatography (temperature program: $145^{\circ} \mathrm{C}$ for $5 \mathrm{~min}$, rising to $210^{\circ} \mathrm{C}$ at a rate of $2^{\circ} \mathrm{C} / \mathrm{min}$ and held at this temperature for $10 \mathrm{~min}$; the temperature of the detector and the injector were set at $260^{\circ} \mathrm{C}$ ).

Many factors such as $\mathrm{pH}$, duration, temperature, substrate, enzyme concentration, and stirring speed affected the course of lipase hydrolysis. Consequently, these factors were studied collectively in order to find the optimal conditions to obtain the most effective hydrolysis conditions. Because many parameters affect responses, Response Surface Methodology (RSM) was effective in replacing the traditional kinetic experiments, in order to quantify the effects of each parameter and interaction between factors (the one-factor at a time ignores interactions between factors which are simultaneously present). A Doehlert experimental design was performed and displayed a uniform 
distribution of the points within the experimental domain and allowed a number of distinct levels for each variable $[24,25]$. The processing variables investigated were reaction time (X1, five levels), flow rate $(X 2$, seven levels) and enzyme/substrate (X3, three levels). The mixture was recirculated using a peristaltic pump at various flow rates in order to increase the contact between enzyme and substrate (Table 1).

Temperature and $\mathrm{pH}$ were fixed at optimal values. The total number of points $(\mathrm{N})$ for three factors $(\mathrm{k})$ was $13\left(N>=k^{2}+k+1\right)$. Sixteen experiments were carried out, the 13th assay was performed at the centre of the experimental domain and was repeated three times [14-16] in order to estimate the residual variance (Table 2).

A full quadratic model containing 10 coefficients including the interaction terms was assumed to describe the relationships between responses, namely $\mathrm{DH}(\mathrm{Y} 1), \%$ of saturated fatty acids in the permeate after filtration (Y2), \% of PUFAs in the permeate after filtration (Y3) and experimental factors

$$
\eta_{k}=\beta_{0}+\sum_{i=1}^{3} \beta_{i} x_{i}+\sum_{i=1}^{3} \beta_{i i} x_{i}{ }_{i=1 j=1+i}^{2}+\sum_{i j}^{3} \beta_{i j} x_{i} X_{j}
$$

Where êta $a_{k}$ refers to the dependent variables; beta $_{0}$ is the constant coefficient; $X_{i}$ are the coded independent variables; beta $_{i}$ are the linear coefficients, beta $_{i j}$ are the second-order interaction coefficients and beta $\mathrm{i}_{\mathrm{ii}}$ are the quadratic coefficients. Results are valid within the experimental domain.

The hydrolysis percentage of salmon oil during enzymatic treatment was measured from the acid value of the reaction mixture and from the saponification value of salmon oil, according to the following equation:

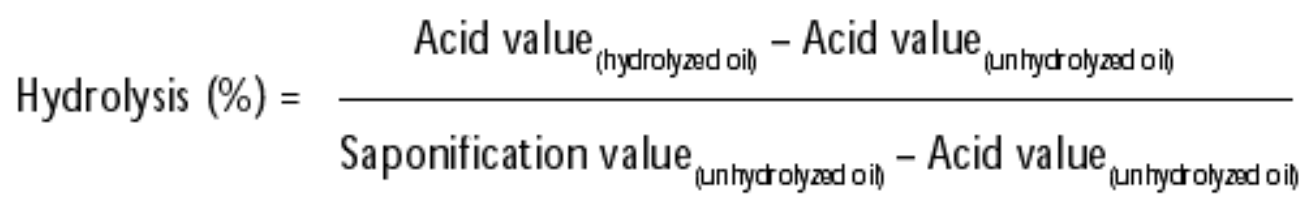

where acid value is expressed as the number of $\mathrm{mg}$ of $\mathrm{KOH}$ required to neutralise free fatty acids present in $1 \mathrm{~g}$ of oil; the saponification value is defined as the number of $\mathrm{mg}$ of $\mathrm{KOH}$ required to saponify $1 \mathrm{~g}$ of oil.

The distribution of lipid classes of salmon oil during hydrolysis by the lipase was determined by latroscan TLC-FID (Iatron Laboratories, Inc., Tokyo, Japan). The latroscan was operated under the following conditions: hydrogen flow rate, $160 \mathrm{ml} / \mathrm{min}$; air flow rate, $21 / \mathrm{min}$; voltage of the detector, $8 \mathrm{mV}$ full scale and scanning speed $0.42 \mathrm{~cm} / \mathrm{s}$. 


\section{Results and discussion}

After two hours of reaction with Neutrase ${ }^{\circ}$, a value of $7.5 \%$ for the DH was sufficient to extract most of the lipid content (Figure 1). The recovery of total lipids $(14.3 \% \mathrm{w} / \mathrm{w})$ was close to the traditional method using solvents $(15.0 \% \mathrm{w} / \mathrm{w})$.

Contour plots could be usefully employed to study response surface and locate the optimum area and relationship between independent and dependent variables. RSM is shown in a two-dimensional representation. Concerning the three responses observed during the action of the lipase, the linear terms, which are b1 for time, b2 for flow rate and b3 for E/S ratio were highly significant $(P<0.01$ or 0.05). The estimated model coefficients beta of the quadratic model were calculated by regression analysis on the experimental responses, and multiple regression coefficients are summarised in Table 3. ANOVA and canonical analysis were used to characterise the validity of the proposed polynomial models. The adequacy of each quadratic model was tested by the lack of fit and the coefficient of determination was $\mathrm{R}^{2}>=82 \%$.

For the response of $\mathrm{DH}$ by lipase, the linear and quadratic terms varied with significant effect $(P 3 / 4$ 0.01). All linear terms were positive. The flow rate is the most significant factor followed by duration and $\mathrm{E} / \mathrm{S}$ ratio. A maximal value of $44.6 \%$ for the hydrolysis degree was predicted with the following conditions: $\mathrm{E} / \mathrm{S}=0.37$; reaction time $=16$ hours; flow rate $=400 \mathrm{~g} / \mathrm{min}$ (Figure 2). However, no further increase of DH could be achieved at longer reaction times. For this reason, the lipolysis was stopped after 15 hours and submitted to the filtration step.

Contour plots of SFA and PUFA contents during the lipolysis are displayed in Figures 3 and 4 . A minimal value of $9.7 \%$ of SFA was observed after 10 hours at a flow rate of $647 \mathrm{~g} / \mathrm{min}$ and $\mathrm{E} / \mathrm{S}=0.4 \%$, whereas a PUFA increase of up to $33.5 \%$ was obtained after 13.6 hours at a flow rate of $436 \mathrm{~g} / \mathrm{min}$ with $\mathrm{E} / \mathrm{S}=0.4 \%$. These data from methyl esters were evaluated according to the $\mathrm{KOH} / \mathrm{MeOH}$ method.

Table 4 shows the distribution of lipid classes, where the triglycerides (TG) decrease over time from the initial value of 97.7 to $66.6 \%$ after 24 hours. The decrease of the TG content would have led to a concomitant increase of monoglycerides. However, the low amount of MG observed after 24 hours seems to result from multiple rearrangements of fatty acids.

According to the optimal conditions of hydrolysis by the lipase, the oil phase recovered from the previous mixture was submitted to filtration as described in the "Materials and methods" section. Two fractions, namely permeate and retentate, were recovered and analysed after the filtration step. As shown in Table 5, the amount of SFA decreased considerably $(-33.7 \%)$ in the permeate and increased in the retentate $(+33.3 \%)$. These data clearly show that the filtration retained the SFA in the retentate. Monoenic FA, PUFA n- 6 and $n-3$ increased by $+13.5,11.5$ and 9.3\%, respectively.

Proteolytic and lipolytic enzymes lead to a rapid extraction of total lipids from fish products under mild conditions and without solvents. A subsequent filtration step, under controlled parameters such as temperature, pressure and membrane porosity among others, allowed significant concentration of polyunsaturated fatty acids. This process may be easily scaled up and applied to a wide range of fish products. 
To date, different works on hydrophobic and hydrophilic membranes are carried out in our laboratory to improve the knowledge on the interactions that may occur between these molecules and the membrane materials.

\section{CONCLUSION}

\section{Acknowledgements}

This investigation was supported by the fish processing company "les Salaisons Maritimes André Ledun" to whom the authors are grateful for the permission to publish this work.

\section{REFERENCES}

1. KOLANOWSKI W, SWIDERSKI F, BERGER S (1999). Possibilities of fish oil application for food products enrichment with omega-3 PUFA. Int J Food Sci Nutr, 50: 39-49.

2. SHAHIDI F, WANASUNDARA UN (1998). Omega-3 fatty acid concentrates: nutritional aspects and production technologies. Trends Food Sci Technol, 9: 230-40.

3. SIMOPOULOS AP (1997). Essential fatty acids in health and chronic disease. Food Rev Int, 13: 62331.

4. MINNIS RC, HAQ IU, JACKSON PR, YEO WW, RAMSAY LE (1998). Oily fish and fish oil supplements in the prevention of coronary heart disease. J Human Nutr Dietetics, 11: 13-9.

5. RAMBJOR GS, WALEN AI, WINDSOR SL, HARRIS WS (1996). Eicosapentaenoic acid is primarily responsible for hypotriglyceridemic effect of fish oil in humans. Lipids 31: S45-9.

6. ACKMAN RG (1999). Docosahexaenoic acid in the infant and its mother. Lipids, 34: 125-8.

7. GANDHI NN (1997). Review: applications of lipase. J Am Oil Chem Soc, 74: 621-34.

8. BALCAO VM, PAIVA AL, MALCATA FX (1996). Bioreactors with immobilized lipases: state of the art. Enzyme Microbial Technol, 18: 392-416.

9. WANASUNDARA UN, SHAHIDI F (1998). Lipase-assisted concentration of $n-3$ polyunsaturated fatty acids in acylglycerols from marine oils. J Am Oil Chem Soc, 75: 945-51.

10. WANASUNDARA UN, SHAHIDI F (1998). Concentration of omega-3 polyunsaturated fatty acids of marine oils using Candida cylindracea lipase: optimization of reaction conditions. J Am Oil Chem Soc, 75: 1767-74.

11. SHIMADA YK, MARUYAMA A, SUGIHARA S, MORIYAMA U, TOMINAGA Y (1997). Purification of docosahexaeonic acid from tuna oil by a two-step enzymatic method: hydrolysis and selective esterification. J Am Oil Chem Soc, 74: 1441-6. 
12. HARALDSSON GG, KRISTINSSON B, SIGURDARDOTTIR R, GUDMUNDSSON GG, BREIVIK H (1997). The preparation of concentrates of eicosapentaenoic acid and docosahexaenoic acid by lipasecatalyzed transesterification of fish oil with ethanol. J Am Oil Chem Soc, 74: 1419-24.

13. PARMENTIER M, FANNI J (1998). Les techniques membranaires : quel avenir dans le domaine des corps gras ? OCL, 5: 363-6.

14. RAMAN LP, CHERYAN M, RAJAGOPALAN N (1996). Solvent recovery and partial deacidification of vegetable oils by membrane technology. Fett/Lipid, 98: 10-4.

15. RAMAN LP, CHERYAN M, RAJAGOPALAN N (1996). Deacidification of soybean oil by membrane technology. J Am Oil Chem Soc, 73: 219-24.

16. ZWIJNENBERG HJ, KROSSE AM, EBERT K, PEINEMANN KV, CUPERUS FP (1999). Acetone-stable nanofiltration membranes in deacidifying vegetable. Oil J Am Oil Chem Soc, 76: 83-7.

17. KALE V, KATIKANENI SPR, CHERYAN M (1999). Deacidifying rice bran oil by solvent extraction and membrane technology. J Am Oil Chem Soc, 76: 723-7.

18. SUBRAMANIAN R, NAKAJIMA M (1997). Membrane degumming of crude soybean and rapeseed oils. J Am Oil Chem Soc, 74: 971-5.

19. ADLER-NISSEN J (1986). Enzymic hydrolysis of food proteins. London: Elsevier Applied Science Publishers.

20. LINDER M, FANNI J, PARMENTIER M, REGNAULT $P$ (1995). Procédé d'obtention d'une base protéique d'origine animale présentant des propriétés nutritionnelles, aromatisantes et gélifiantes adaptées à la formulation de produits alimentaires n 9509789.

21. AURSAND M, JORGENSEN L, GRASDALEN H (1995). Positional distribution of omega3 fatty acids in marine lipid triacylglycerols by high-resolution ${ }^{13} \mathrm{C}$ nuclear magnetic resonance spectroscopy. J Am Oil Chem Soc, 72: 293-7.

22. ACKMAN RG, OROZCO VR, RATNAYAKE WMN (1991). Aspects of positional distribution of fatty acids in triacylglycerols of skin, white and dark muscle of Mackerel Scomber scombrus in relation to hypertension. Fat Sci Technol, 12: 447-50.

23. ANDO Y, OTA T, MATSUHIRA Y, YAZAWA K (1996). Stereospecific analysis of triacyl-sn-glycerols in docosahexaenoic acid-rich fish oils. J Am Oil Chem Soc, 73: 483-7.

24. DOEHLERT DH (1970). Uniform shell designs. App/ Statistics, 19: 231-9.

25. MATHIEU D, PHAN-TAN-LUU R (1998). LPRAI Université d'Aix-Marseille, NEMROD ${ }^{\circ}$ : New Efficient Methodology for Research using Optimal Design. 
Illustrations

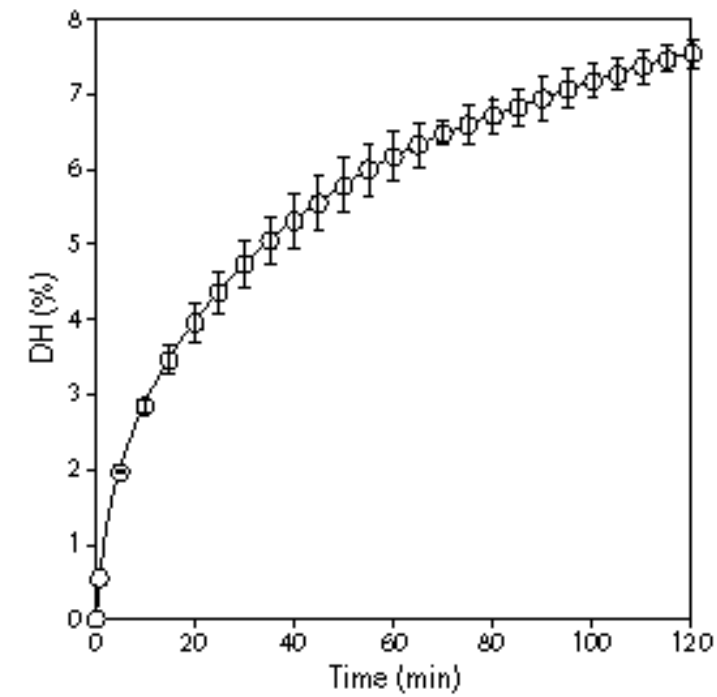

Figure 1. Course of hydrolysis of salmon flesh by Neutrase 0.51; $p H$ 7.0; distilled water [1:1] enzyme: $50 \mathrm{~g} / \mathrm{kg}$ salmon protein.

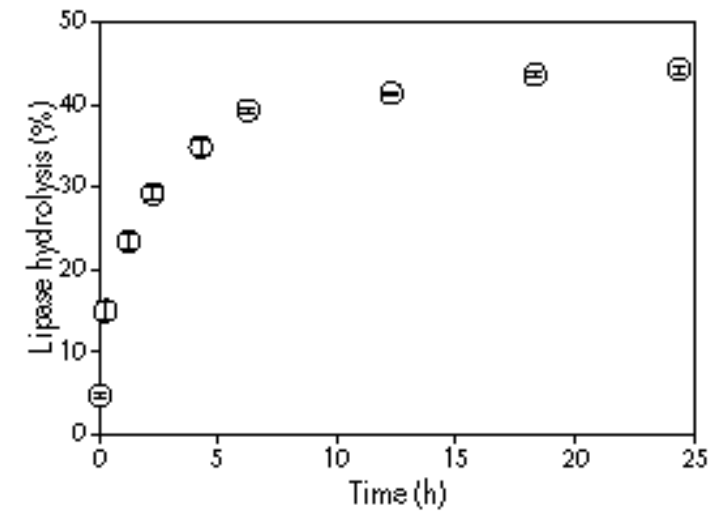

Figure 2. Course of the hydrolysis degree of salmon oil by lipase $\left(37^{\circ} \mathrm{C}\right.$, oil/distilled water [1:1]; 40 Kilo Lipase Units). 


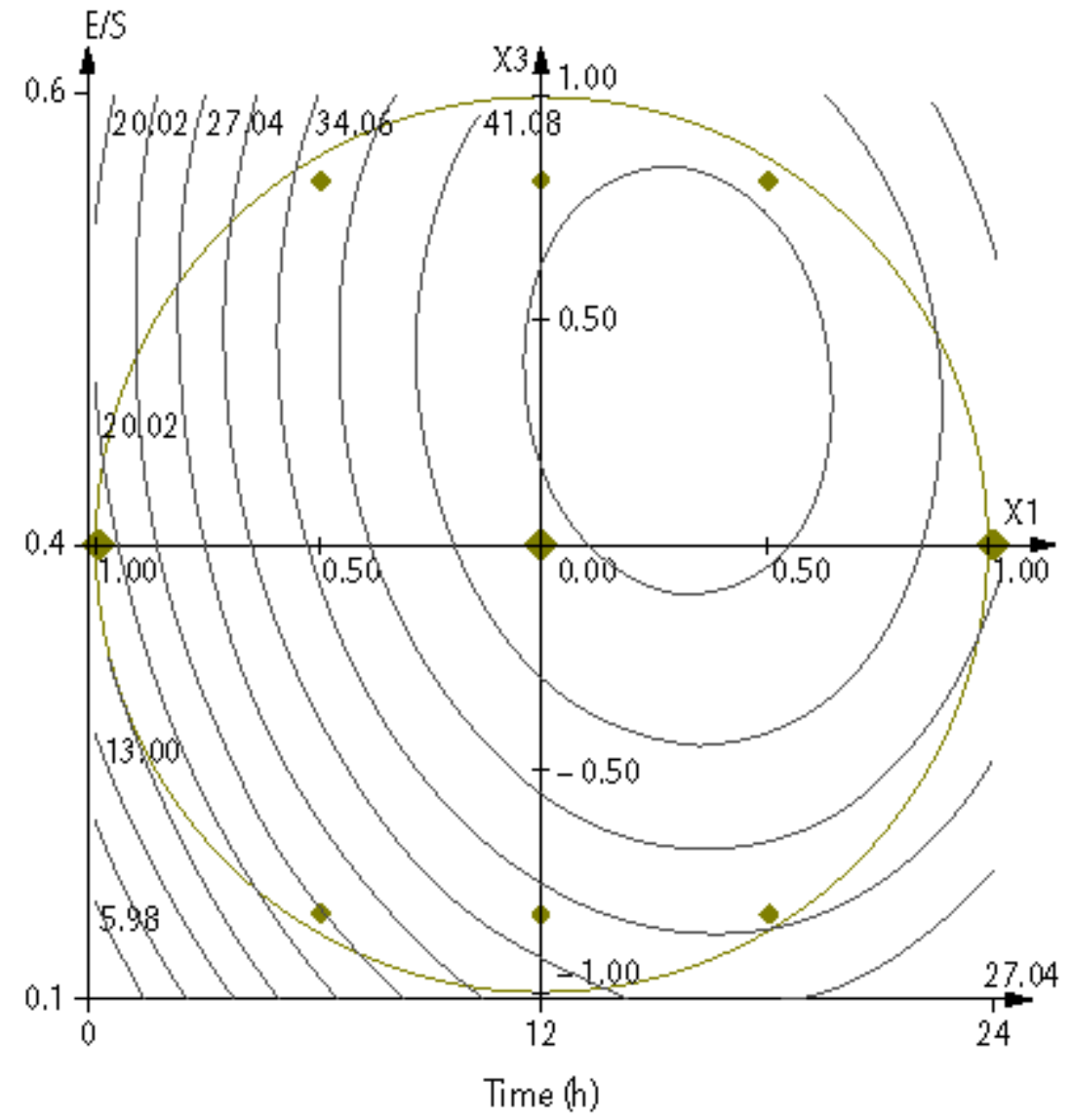

Figure 3. Response surface for the effect of $E / S$ and time on hydrolysis degree (\%) of salmon oil treated by lipase SP 398. 


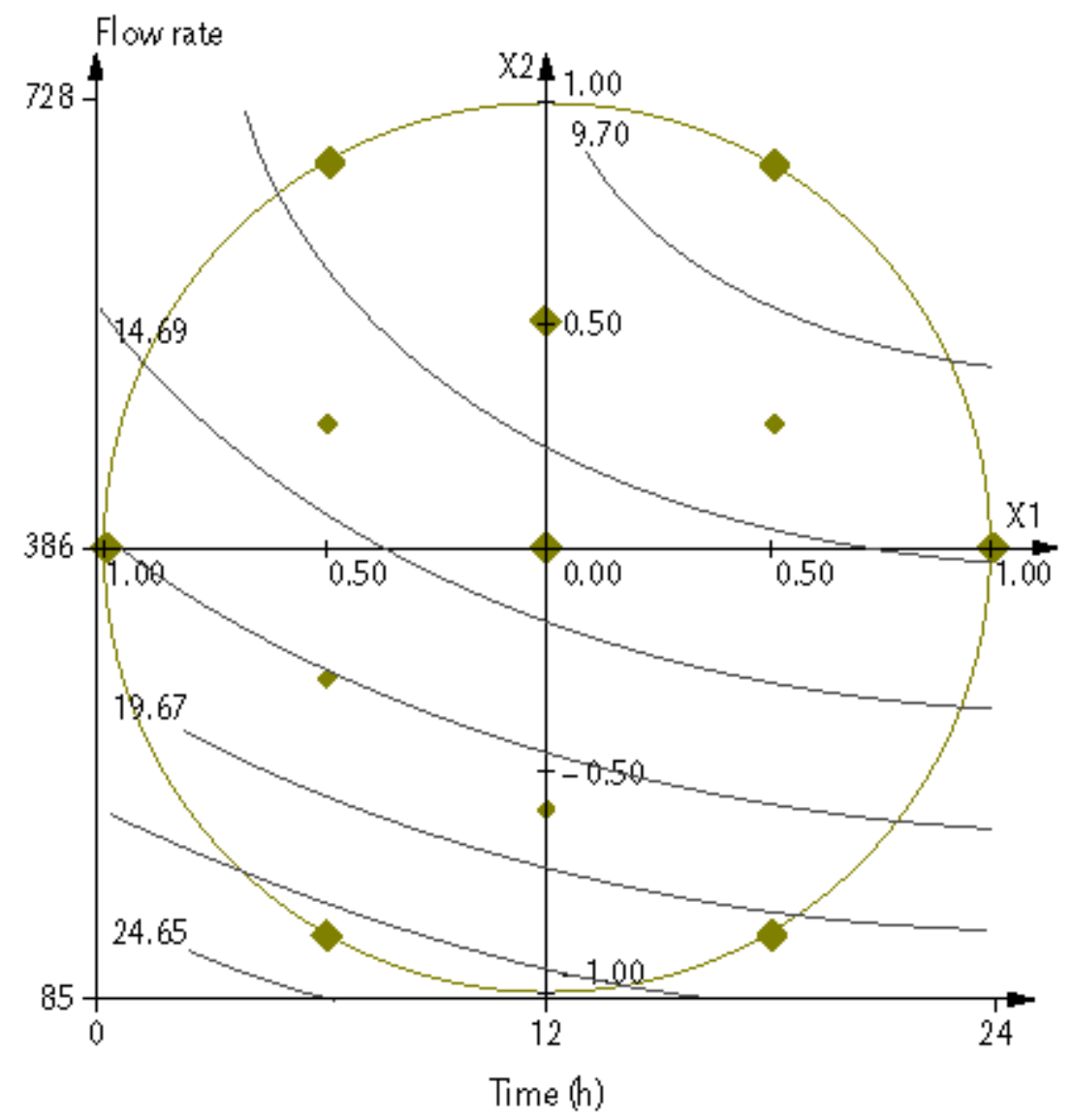

Figure 4. Response surface for the effect of flow rate $(\mathrm{g} / \mathrm{min})$ and time on saturated fatty acids amount in the permeate (\%) after filtration of salmon oil treated 10 hours by lipase SP 398. 


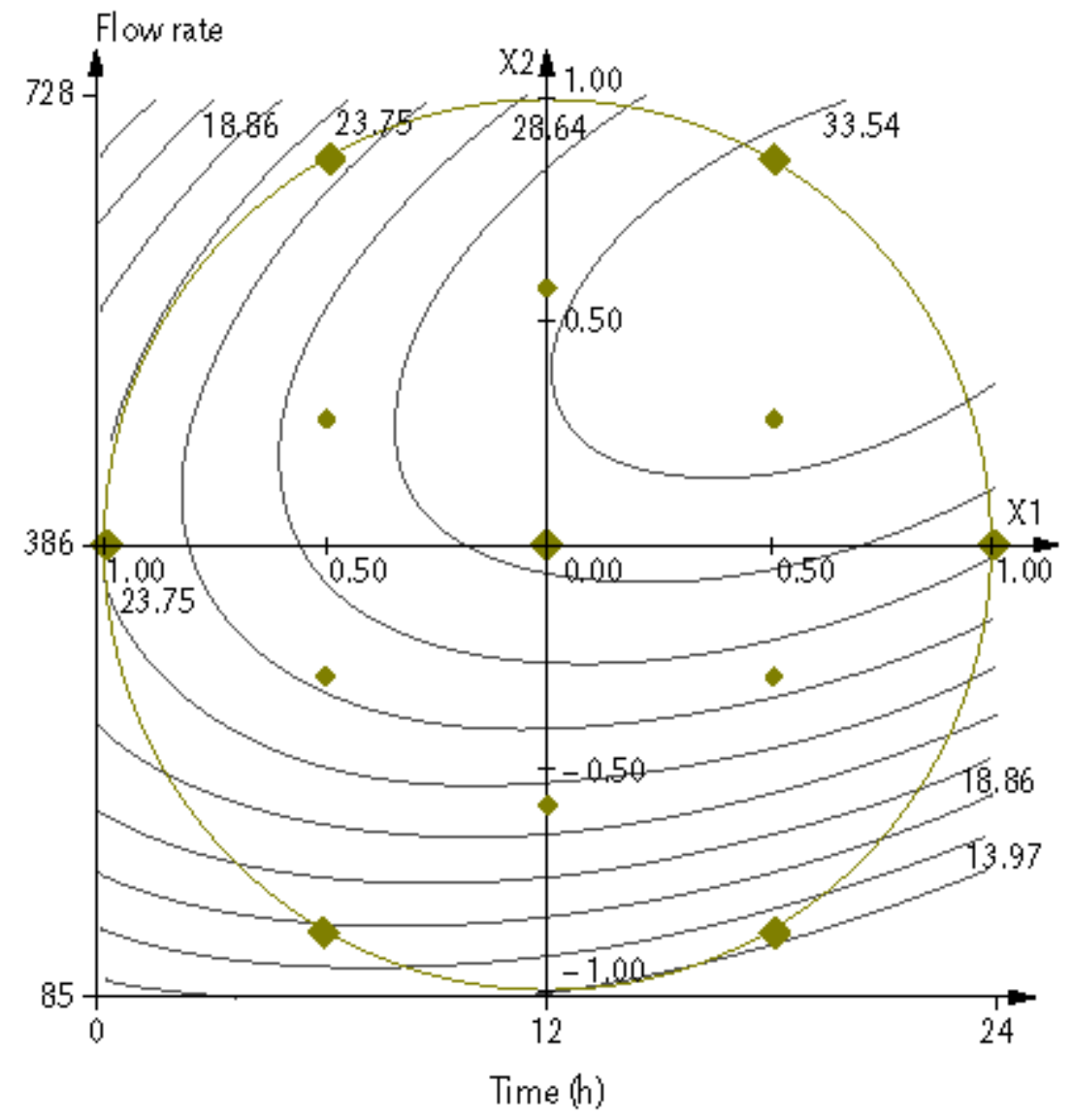

Figure 5. Response surface for the effect of flow rate $(\mathrm{g} / \mathrm{min})$ and time $(\mathrm{h})$ on polyunsatured fatty acids amount in the permeate (\%) after filtration of salmon oil treated 10 hours by lipase SP 398.

Table 1. Experimental domain and level distribution of the variables used in the lipase hydrolysis of $n-3$ polyunsaturated fatty acids of saimon oil.

\begin{tabular}{|l|c|c|c|}
\hline Independent variables & Symbol & Levels & \multicolumn{1}{|c|}{ Experimental values } \\
\hline Reaction time (h) & $\mathrm{X} 1$ & 5 & 0.256 .2512 .2518 .2524 .25 \\
Flow rate (g/min) & $\mathrm{X} 2$ & 7 & 93197276386486566728 \\
Enzyme/substrate & $\mathrm{X} 3$ & 3 & 0.20 .40 .6 \\
\hline
\end{tabular}


Table 2. Doehlert uniform shell design for three variables (X1 reaction time, $X 2$ flow rate and $X 3$ enzyme/substrate) and responses for salmon oil hydrolysis by lipase SP 398.

\begin{tabular}{|c|c|c|c|c|c|c|}
\hline \multirow[b]{2}{*}{ Run } & \multirow[b]{2}{*}{ X1 } & \multirow[b]{2}{*}{$\mathbf{X 2}$} & \multirow[b]{2}{*}{$\mathbf{x} 3$} & \multicolumn{3}{|c|}{ Responses Y (\%) } \\
\hline & & & & \multicolumn{3}{|c|}{$\%$ in mixture during lipolysis } \\
\hline 1 & 1.0000 & 0.0000 & 0.0000 & 43.20 & 12.15 & 27.75 \\
\hline 2 & -1.0000 & 0.0000 & 0.0000 & 13.00 & 17.20 & 25.21 \\
\hline 3 & 0.5000 & 0.8660 & 0.0000 & 43.10 & 11.42 & 38.43 \\
\hline 4 & -0.5000 & -0.8660 & 0.0000 & 5.98 & 20.49 & 11.52 \\
\hline 5 & 0.5000 & -0.8660 & 0.0000 & 6.84 & 17.62 & 12.71 \\
\hline 6 & -0.5000 & 0.8660 & 0.0000 & 35.70 & 14.36 & 24.66 \\
\hline 7 & 0.5000 & 0.2887 & 0.8165 & 43.20 & 7.21 & 34.13 \\
\hline 8 & -0.5000 & -0.2887 & -0.8165 & 20.60 & 14.04 & 25.85 \\
\hline 9 & 0.5000 & -0.2887 & -0.8165 & 26.95 & 13.09 & 24.84 \\
\hline 10 & 0.0000 & 0.5774 & -0.8165 & 31.80 & 11.26 & 25.25 \\
\hline 11 & -0.5000 & 0.2887 & 0.8165 & 38.00 & 11.95 & 31.88 \\
\hline 12 & 0.0000 & -0.5774 & 0.8165 & 30.77 & 34.62 & 29.15 \\
\hline 13 & 0.0000 & 0.0000 & 0.0000 & 42.00 & 14.10 & 32.51 \\
\hline 14 & 0.0000 & 0.0000 & 0.0000 & 44.60 & 13.74 & 31.84 \\
\hline 15 & 0.0000 & 0.0000 & 0.0000 & 44.20 & 13.00 & 31.00 \\
\hline 16 & 0.0000 & 0.0000 & 0.0000 & 44.00 & 13.50 & 31.50 \\
\hline
\end{tabular}

Degrœe of hydrolysis: DH; Saturated Fatty Acids: SFA; Polyursatur ated Fatty Acids: PUFA. 
Table 3. Regression coefficient of predicted quadra tic polynomial models.

\begin{tabular}{|c|c|c|c|c|}
\hline \multicolumn{2}{|l|}{ Variables } & $\begin{array}{l}\text { DH } \\
\text { (\%) }\end{array}$ & $\begin{array}{l}\text { SFA } \\
(\%)\end{array}$ & $\begin{array}{l}\text { PUFA } \\
\text { (\%) }\end{array}$ \\
\hline \multicolumn{2}{|l|}{ Interœept } & $43.70^{444}$ & $13.58^{444}$ & $31.71^{444}$ \\
\hline \multicolumn{5}{|l|}{ Linør } \\
\hline Time & b1 & $10.02^{444}$ & $-2.70^{444}$ & $2.66^{44}$ \\
\hline Flow rate & $\mathrm{b} 2$ & $16.86^{444}$ & $-6.62^{444}$ & $8.95^{444}$ \\
\hline$E / S$ & b3 & $6.66^{4 * 4}$ & $3.14^{4+4}$ & $3.82^{444}$ \\
\hline \multicolumn{5}{|c|}{ Quadratic } \\
\hline & b11 & $-15.60 * 4$ & 1.09 & $-6.23^{44}$ \\
\hline & b22 & $-22.53^{444}$ & $282^{44}$ & $-11.43^{44}$ \\
\hline & b33 & $-8.18^{44}$ & $169^{*}$ & -0.63 \\
\hline \multicolumn{5}{|c|}{ Inter $x$ tion } \\
\hline & b12 & 3.77 & -0.04 & $7.26^{44}$ \\
\hline & b13 & -2.04 & $-2.31^{+}$ & -0.57 \\
\hline & b23 & -1.17 & $-15.46^{444}$ & 0.60 \\
\hline $\mathrm{R}^{R}$ & & 0.94 & 0.82 & 0.87 \\
\hline
\end{tabular}

Table 4. Distribution of the different lipid classes in salmon oil hydrolysed by lipase SP398 (data are reported as uncorrected TLC FID area percent).

\begin{tabular}{c|c|c|c|c|c|c} 
& TG & FFA & 1,3-DG & 1,2-DG & MG & Polar \\
\hline Initial & 97.7 & 1.2 & 0.3 & 0.5 & Nd & 0.3 \\
Oh15 & 65.7 & 13.3 & 6.6 & 9.4 & 3.3 & 1.7 \\
$6 \mathrm{~h} 15$ & 61.7 & 20.4 & 5.8 & 4.5 & 6.1 & 1.5 \\
$12 \mathrm{~h} 15$ & 66.7 & 20.6 & 4.4 & 2.7 & 3.2 & 2.3 \\
$18 \mathrm{~h} 15$ & 71.3 & 20.0 & 3.7 & 2.0 & 2.0 & 1.1 \\
$24 \mathrm{~h} 15$ & 66.6 & 22.4 & 3.5 & 2.9 & 3.8 & 0.8
\end{tabular}

Nd: not determined; Trighyorida: TG; Dighyoride: DG; Monoghyoride: MG.

Table 5. Composition of fatty acids from initial salmon oil and composition of the different fractions after lipase hydrolysis.

\begin{tabular}{l|c|c|c|c}
$\begin{array}{l}\text { Fatty acids) } \\
\text { (mg/g }\end{array}$ & $\begin{array}{c}\text { nitial } \\
\text { oil }\end{array}$ & $\begin{array}{c}\text { Hydrolysed } \\
\text { oil }\end{array}$ & $\begin{array}{c}\text { Permeate } \\
\text { (hydrolysed oil) }\end{array}$ & $\begin{array}{c}\text { Retentate } \\
\text { (hydrolysed oil) }\end{array}$ \\
\hline$\sum$ saturated & 249 & 248 & 165 & 332 \\
$\sum$ monoenic & 304 & 310 & 345 & 280 \\
$\sum n-6$ & 65 & 65 & 72.5 & 58.4 \\
$\sum n-3$ & 335 & 332 & 366 & 295 \\
$\sum$ other fatty acids & 38 & 45 & 52.3 & 40.2
\end{tabular}

